StanisŁaw SALA

Uniwersytet Humanistyczno-Przyrodniczy Jana Kochanowskiego, Kielce

\title{
Wybrane problemy metodologiczne badań procesów globalizacji
}

Jednym z najmodniejszych i najczęściej używanych pojęć jest pojęcie globalizacji. Paradoksem jest, że im częściej jest ono używane, tym większe są kontrowersje dotyczące jego znaczenia. Po raz pierwszy termin ten pojawił się na gruncie ekonomii w 1959 roku. W latach 70. XX wieku zaczęto go używać w naukach społecznych, przy czym największą popularność zyskał dopiero w latach 90. XX wieku. Obecnie powszechnie używa się tego określenia w naukach ekonomicznych, geograficznych, społecznych czy politycznych. Uwzględniając zakres merytoryczny, pojęcie to jest bardzo często nadużywane. Poszczególni autorzy wykorzystują je do opisu wielu procesów faktycznie nie mających nic wspólnego z globalizacją. Jest to pojęcie modne, do dobrego tonu należy mówienie o globalizacji. Wykorzystywane jest również do opisywania nowych, nieznanych procesów zachodzących we współczesnym świecie.

Pierwotnie globalizację traktowano jako jednorodny proces odciskający swe piętno na gruncie nauk ekonomicznych i społecznych. Później jednak uświadomiono sobie, że globalizacja niesie ze sobą wiele procesów, z których część znamy, natomiast jeszcze wielu nie jesteśmy świadomi. W tym kontekście bardziej właściwe jest pisanie i mówienie nie o globalizacji, lecz o procesach globalizacji.

Szybko zmieniająca się rzeczywistość społeczno-gospodarcza i polityczna wymusza zmiany w samej geografii ekonomicznej, politycznej czy regionalnej. W czasach dominacji gospodarki ilościowej najważniejszą gałęzią gospodarki był przemysł. Istniejące wówczas przedsiębiorstwa można było jasno przyporządkować do określonej branży przemysłu. Obecnie w dobie funkcjonowania gospodarki jakościowej znacznie trudniej jest określić branżę, w jakiej funkcjonuje dana korporacja. Wynika to $\mathrm{z}$ faktu bardzo dużej labilności poszczególnych korporacji, które z jednej strony są w stanie w stosunkowo krótkim czasie uruchomić produkcję $\mathrm{w}$ dowolnym rejonie świata, natomiast z drugiej - potrafią równie szybko zmienić branżę lub zlikwidować daną fabrykę czy filię. Tradycyjna geografia społeczno-ekonomiczna posiadała strukturę zgodną ze strukturą starej gospodarki. W obliczu współczesnych wyzwań ze strony korporacji transnarodowych ta struktura staje się niewydolna, ponieważ nie potrafi kompleksowo zdiagnozować przyczyn, mechanizmów i konsekwencji ich działalności. Było to przyczyną unikania przez geografów społeczno-ekonomicznych badań nad szeroko rozumianymi procesami globalizacji. Jednakże, rozumiejąc wyzwania współczesności, obecnie coraz więcej geografów zaczyna wypowiadać się na temat różnych aspektów globalizacji (Bonasewicz 2003, Czerny 2005, Korcelli-Olejniczak 
1997, Domański 1996, 2001, 2002, Jędrzejczyk 2002, Kuciński 1999, Gierańczyk 2003, Gierańczyk, Stańczyk, Gorynia, Owczarek 2004, Makieła 2003, Markowski 2003, Sala 2003, Stryjakiewicz 1988, 2003, Zioło 1999, 2003, Wieloński 2003).

\section{ZARYS PROBLEMÓW METODOLOGII BADAŃ GEOGRAFII}

Obecnie globalizacja jest jednym z najważniejszych zjawisk politycznych, społecznych czy gospodarczych. Bez względu na nasze poglądy czy też miejsce zamieszkania, konsekwencje procesów globalizacji dotyczą praktycznie każdej jednostki na kuli ziemskiej w sposób bezpośredni lub pośredni. Wielokierunkowość oddziaływań i różnorodność podejść sprawia, że w badaniach należy kierować się podejściem interdyscyplinarnym. Tylko wtedy, kiedy wyzwolimy się z ograniczeń wynikających z metodologii danej dyscypliny badawczej, możliwe będzie uchwycenie istoty globalizacji.

Zagadnienie globalizacji rozpatrywane jest na gruncie nauk społecznych, politycznych, ekonomicznych i ekologicznych. Dlatego próba stworzenia spójnej syntezy wymaga wyzwolenia się z ograniczeń charakteryzujących szczegółowe dyscypliny naukowe.

W geografii ekonomicznej i społecznej istnieje bogata literatura poświęcona metodologii i metodyce badań. Do nowszych pozycji należy zaliczyć między innymi prace Z. Chojnickiego (1977, 1986, 1990, 1999, 2001, 2002),Z. Rykla(1991, 2001), B. Domańskiego (1963, 1976, 1977, 1982, 1987, 1996, 2001, 2002, 2003), T. Stryjakiewicza (2001), M. Czerny (2001, 2005), M. Czerny, R. Łuczaka, J. Makowskiego (2007), K. Rembowskiej (2001).

Wąska specjalizacja oparta na założeniach pozytywistycznych w geografii ma daleko idące konsekwencje. Wypracowywane na tej drodze modele, pomimo iż są wewnętrznie spójne, w coraz mniejszym stopniu tłumaczą i wyjaśniają nam otaczającą nas rzeczywistość. Konsekwencją tego stanu rzeczy jest postępująca marginalizacja geografii zarówno jako dyscypliny naukowej, jak i jako przedmiotu nauczania.

Trudności w doborze metod badawczych wynikają przede wszystkim z bardzo złożonego charakteru problemów występujących w temacie globalizacji, które znajdują się na granicy między różnymi naukami szczegółowymi, takimi jak: ekonomia, geografia polityczna, geografia społeczna, politologia, geografia ekonomiczna czy socjologia. Duża liczba zmiennych występujących w układach polityczno-gospodarczych uniemożliwia wyróżnienie prostych relacji typu przyczyna-skutek. Sytuację dodatkowo komplikują elementy środowiska fizyczno-geograficznego, które niejednokrotnie leżą u podstaw faktów społeczno-gospodarczych.

W geografii społeczno-ekonomicznej percepcja podmiotu determinuje postrzeganie faktów i zjawisk, przyczyniając się tym samym do ukonstytuowania się podejścia idiograficznego. Procesy globalizacji obejmują szerokie spectrum faktów obejmujących zjawiska społeczne, gospodarcze, polityczne czy ekologiczne. Zastosowanie podejścia idiograficznego pozwala w pełni zrozumieć i wyjaśnić mechanizm globalizacji.

W tym przypadku na uwagę zasługuje podejście humanistyczne, które stoi w sprzeczności metodologicznej z podejściami mającymi podbudowę pozytywistyczną czy neopozytywistyczną. Z punktu widzenia podejścia humanistycznego metody ilościowe, zwłaszcza modelowanie matematyczne, nie zapewniają obiektywizmu procesu badawczego, ponieważ problemy polityczne, społeczne czy kulturowe nie dają się ująć i zinterpretować w spo- 
sób poprawny. Matematyzacja zagadnień społecznych prowadzi do powstania wewnętrznie spójnych koncepcji, które jednak są nadmiernie uproszczone i nie oddają istoty rzeczy, a w szczególności wysokiego stopnia komplikacji zagadnień społecznych. Według Chojnickiego (2001), podejście humanistyczne koncentruje się na krytyce innych podejść. Jednak w ujęciu humanistycznym pierwszoplanową rzeczą jest niestosowanie skomplikowanych metod, które w konsekwencji prowadzą do wątpliwej wartości wniosków, natomiast najważniejszą kwestią są konkretne treści, problemy oraz procesy, które wypełniają sferę społeczną. Z punktu widzenia jednostki czy społeczeństwa, kluczowego znaczenia nabierają kwestie związane z rozpoznaniem aktualnych procesów zachodzących na płaszczyźnie społeczno-ekonomicznej oraz określeniem głównych tendencji współczesnych przemian.

\section{PodeJŚCIE SYSTEMOWE}

Na uwage zasługuje podejście systemowe w ujęciu idiograficznym, które polega na wartościowaniu i wyjaśnianiu faktów i zjawisk społecznych, gospodarczych i politycznych z punktu widzenia koncepcji.

Podejście systemowe przynależy do ogólnej teorii systemów, opracowanej przez biologa Ludwiga von Bertalanffy'ego, który wyprowadził ją z teorii systemów otwartych (Bertalanffy 1950, 1956, 1962, 1968). Polega ono na takim rozwiązywaniu problemów, w którym badane zjawiska są traktowane w sposób kompleksowy. W przeciwieństwie do dyscyplin szczegółowych podejście systemowe nie posiada ani swoich metod badawczych, pozwalających na zbadanie danego zjawiska, ani aparatu formalnego i środków technicznych potrzebnych do pracy z systemami. Podejście systemowe nie posiada również przedmiotu badań. W praktyce podejście systemowe należy uznać jako przeciwstawne podejściu mechanistycznemu, w którym zjawiska traktowane są kompleksowo w sposób całościowy. W podejściu mechanistycznym błędnie uważa się, że zjawiska można tylko wtedy zrozumieć, kiedy zredukuje się je do podstawowych części, a następnie pozna się ich właściwości. W tym znaczeniu podejście systemowe podobne jest do podejścia holistycznego funkcjonującego w naukach humanistycznych. Kompleksowe traktowanie zjawisk pozwala na spojrzenie na nie w sposób całościowy, z uwzględnieniem ich zależności zewnętrznych i wewnętrznych. W okresie dynamicznego rozwoju gospodarki światowej fundamentalnej zmianie uległy elementarne zadania, które codziennie rozwiązują ludzie. W okresie funkcjonowania gospodarki ilościowej (Druckner 1985) dominowały dwie kategorie zadań, które należało rozwiązać. Pierwsza polegała na określeniu, czy możliwa jest realizacja danego zadania, druga natomiast na określeniu czynności, które należy wykonać w celu realizacji danego zadania. W czasach, kiedy poszczególne zjawiska funkcjonują w zwiększającej się współzależności, takie podejście już nie wystarczy. Obecnie w dobie funkcjonowania gospodarki jakościowej coraz większego znaczenia nabierają następujące zagadnienia:

- określenie zadania do wykonania w danej sytuacji,

- wybór najskuteczniejszego sposobu rozwiązania danego zadania,

Uwzględniając skomplikowaną sytuację polityczną i społeczno-gospodarczą współczesnego świata, tylko podejście systemowe daje nadzieję na wypracowanie najkorzystniejszego wariantu umożliwiającego rozwiązanie danego problemu. Kierując się podejściem systemowym nie można zapominać, że pomimo pozytywnych efektów współczesnej rewolucji 
naukowo-technicznej, a w szczególności teleinformatycznej nie jesteśmy w stanie stwierdzić wszystkich istniejących powiązań pomiędzy danymi zjawiskami, w wielu przypadkach możemy się jedynie domyślać stopnia powiązania danego zjawiska z otoczeniem. Współcześnie za podstawowy cel badań politycznych i społeczno-ekonomicznych za pomocą podejścia systemowego należy uznać przetrwanie gatunku Homo sapiens. Wiadomo, że rozwój człowieka polega na ciąłym odchodzeniu od natury. Jeżeli ten proces następuje zbyt wolno, wtedy mamy do czynienia z niedorozwojem politycznym czy społeczno-gospodarczym krajów czy regionów. Natomiast kiedy proces odchodzenia od natury postępuje zbyt szybko, wtedy bezpośrednio pociąga za sobą negatywne zjawiska w postaci lęków związanych z trudnościami adaptacyjnymi do nowych, nieznanych warunków zewnętrznych. Tak więc rozwój musi być zrównoważony, nie może on być ani zbyt szybki, ani zbyt wolny.

Według Mesarovica (1964) istnieją cztery podstawowe podejścia do ogólnej teorii systemów:

- pierwsze zmierza do opracowania sformalizowanych sposobów definiowania systemów,

- drugie dąży do słownego opisu systemu. Jest to podejście przeciwstawne pierwszemu, broniące się przed formalizacją,

- trzecie traktuje teorię systemów jako punkt widzenia, z którego rozwiązuje się dany problem,

- czwarte zmierza do stworzenia rozległego zbioru metod w celu dokonywania rożnego rodzaju syntez.

Procesy globalizacji traktowane w kategoriach systemu charakteryzują się bardzo dużą złożonością. W tym przypadku proste mechanistyczne podejścia badawcze bazujące na rozumowaniu typu przyczyna-skutek zawodzą. Również niewłaściwe wydają się podejścia sformalizowane, które podobnie jak w przypadku podejść mechanistycznych nie radzą sobie z systemami, w których występuje duża liczba niewiadomych. Uogólniając, można przyjać, że wraz ze wzrostem komplikacji systemu maleje przydatność metod sformalizowanych, a tym samym wzrasta znaczenie metod opisowych, których podstawowym celem jest opis istniejącej sytuacji oraz przedstawienie głównych tendencji zmian.

\section{WYJAŚNIANIE, WATROŚCIOWANIE A OBIEKTYWIZM BADACZA}

W geografii problematyka wartościowania została zaprezentowana w pracy D. Harveya (1969) oraz A. Buttimer (1974) i od tego czasu stosowana jest zarówno w podejściu idiograficznym, jak i nomotetycznym. Występujący w tym przypadku problem obiektywności jest głównym przedmiotem sporów metodologicznych. Poprzez aklamację przyjmuje się, że w modelu naturalistycznym stosuje się metody obiektywne, a w modelu humanistycznym „obiektywizm” jest skażony subiektywizmem.

W geografii społeczno-ekonomicznej istnieje nierozstrzygnięty spór metodologiczny pomiędzy orientacją humanistyczną a scjentystyczną, pozytywistyczną czy naturalistyczną dotyczący obiektywizacji faktów (Chojnicki 1986, 1999, 2001). W modelu naturalistycznym ukształtował się sposób dochodzenia do obiektywnej prawdy przejęty z geografii fizycznej, która fakty geograficzne (empiryczne) uzyskuje na drodze bezpośredniej obserwacji. W geografii społeczno-ekonomicznej fakty empiryczne należy znacznie szerzej pojmować 
w stosunku do szeroko ujmowanej geografii fizycznej. Fakty empiryczne uzyskuje się również $\mathrm{w}$ drodze szeroko pojmowanej obserwacji rzeczywistości, a nie tylko z danych przedstawionych $\mathrm{w}$ postaci zapisu matematycznego. W przypadku interpretacji humanistycznej istotna jest ranga podejmowanego tematu oraz dążenie do obiektywizmu, w szczególności $\mathrm{w}$ trakcie stosowania nieprecyzyjnych metod powtarzalnych. Podejście humanistyczne „polega na interpretacji doświadczenia człowieka w jego dwuznaczności, ambiwalencji i złożoności” (Yi Fu Tuan 1976, za: Chojnicki 2001, s. 20).

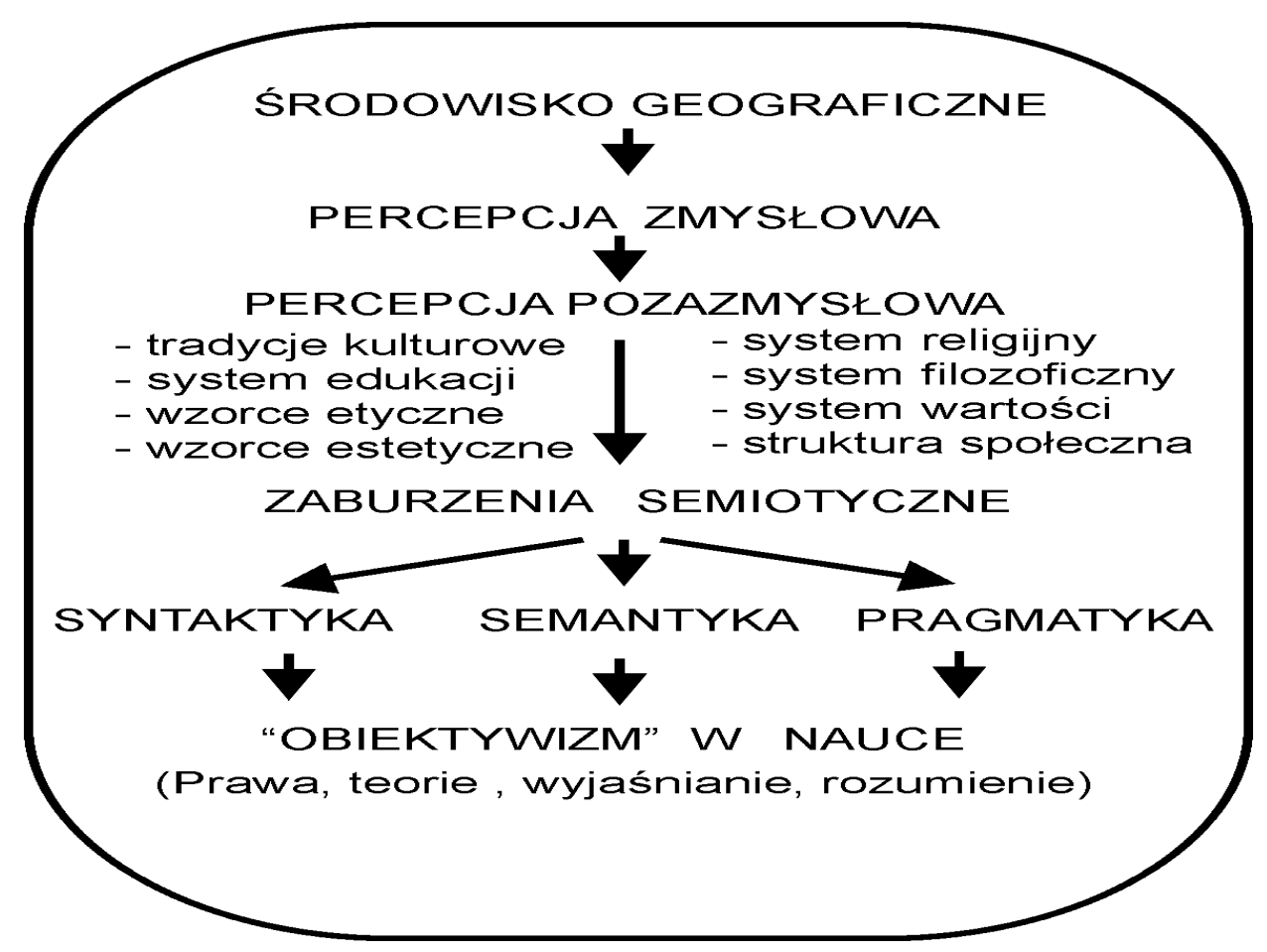

Ryc. 1. Zaburzenia obiektywizmu w geografii

Źródło: Opracowanie własne

Większość badaczy niesłusznie przekonana jest o rzekomym obiektywizmie swoich metod badawczych. Takie „obiektywne” metody sprawdzają się tylko w przypadku bardzo prostych rozumowań przyczynowo-skutkowych, w których istnieje mała liczba zmiennych uprawniających do zastosowania podejść charakterystycznych dla nauk ścisłych. Scjentystyczne badania prowadzone $\mathrm{w}$ duchu redukcjonistycznym są bardzo skuteczne w przypadku problemów mało złożonych. Zawdzięczamy im obecny poziom rozwoju techniki czy medycyny. Jednak w przypadku złożonych problemów proste rozumowanie przyczynowo-skutkowe zawodzi, w związku z czym występuje pilna potrzeba sięgnięcia po podejście antyscjentystyczne, głównie fenomenologiczne, akcentujące całościowe postrzeganie procesów i zjawisk. W geografii obydwa podejścia metodologiczne skażone są subiektywizmem badacza. Dopiero mając tę świadomość, należy czynić starania zmierzające do minimalizacji subiektywizmu, którego i tak nie można w całości wyeliminować. 
Na temat wyjaśniania w geografii istnieje wiele poglądów (Harvey 1969, Nagel 1961, Chojnicki 2002). W ujęciu relacjonistycznym „wyjaśnianie jest postępowaniem nie tylko uzasadniającym, lecz także odkrywczym, w toku którego ustala się przesłanki wyjaśniania stanowiące wiedzę o procesach i mechanizmach determinujących występowanie faktów, głównie w odniesieniu do realnych systemów społecznych" (Chojnicki 2002, s. 12). W tym ujęciu na uwagę zasługuje koncepcja mechanizmów polegająca na opisie następujących po sobie faktów lub zjawisk, które determinują powstanie nowego zjawiska charakteryzującego się określonymi cechami. Mechanizmy są natury obserwowalnej, ukrytej, sprawdzalnej czy hipotetycznej. W wielu przypadkach występują problemy z jednoznaczną klasyfikacją analizowanych mechanizmów. Wynika to głównie z faktu, że niejednokrotnie mechanizmy zachodzą na siebie, są częściowo sprawdzalne bądź częściowo ukryte.

Mechanizmy obserwowalne są egzemplifikowane w postaci zjawisk i procesów egzemplifikowanych w publikacjach naukowych czy prasowych. W tym przypadku obserwowalność dokonuje się poprzez opis statystyczny, matematyczny czy humanistyczny.

Mechanizmy ukryte są związane z koncepcją wiedzy jawnej i ukrytej. Wiedza ukryta jest dostępna tylko bardzo wąskiemu kręgowi odbiorców, którzy dzięki niej posiadają przewagę konkurencyjną. W momencie kiedy firma wypracowała nową wiedzę ukrytą, dotychczasowa wiedza ukryta staje się wiedzą jawną, prezentowaną w różnych publikacjach, ponieważ straciła swoje strategiczne znaczenie.

Mechanizmy sprawdzalne są egzemplifikowane za pomocą dostępnych wskaźników makroekonomicznych, natomiast mechanizmy hipotetyczne są przedstawiane $\mathrm{w}$ formie przypuszczeń dotyczących omawianych związków czy powiązań, co do których istnieje przekonanie, że są wysoce prawdopodobne, natomiast istnieją poważne trudności z ich egzemplifikacją wynikającą z procesu utajnienia wiedzy.

\section{Podsumowanie}

Dobór odpowiednich metod badawczych, za pomocą których można badać procesy globalizacji, nastręcza wiele trudności wynikających z faktu, że geografia wypracowała wiele szczegółowych metod badawczych do opisu zjawisk ilościowych (Chojnicki 1977, 1999). Jednak za pomocą metod ilościowych trudno jest opisywać zjawiska jakościowe, które stanowią sedno globalizacji, ponieważ do tej pory geografia nie wypracowała metodologii czy metodyki zjawisk jakościowych.

$\mathrm{Na}$ obecnym etapie badań podejście systemowe w ujęciu idiograficznym pozwala na uchwycenie istoty globalizacji w całej jej złożoności. Na szczególną uwagę zasługuje wyjaśnianie w ujęciu relacjonistycznym, które w ramach koncepcji mechanizmów pozwala w dostateczny sposób wyjaśniać skomplikowane procesy społeczno-gospodarcze czy polityczne współczesnego świata. 


\section{Literatura}

Bertalanffy L. 1950, The Theory of Open Systems in Physics and Biology, „Science” no 3

Bertalanffy L. 1956, General System Theory, [in:] General Systems, vol. 1, Society for General Systems Research, Ann Arbor

Bertalanffy L. 1962, General System Theory, Critical Review, [in:] General Systems, vol. 8, Society for General Systems Research, Ann Arbor

Bertalanffy L. 1968, General System Theory, Braziller, New York

Bonasewicz A. 2003, Przyczyny i skutki procesów globalizacyjnych, [w:] Geograficzne aspekty globalizacji i integracji europejskiej, red. M. Śmigielska, J. Słodczyk, PTG, Opole

Buttimer A. 1974, Values in geography, Washington

Chojnicki Z. 1986, Refleksje dotyczqce teraźniejszości i przyszłości polskiej geografii, „Przegląd Geograficzny", 58, 3

Chojnicki Z. 1990, The anatomy of the crisis of the Polish economy, [in:] Local development in Europe: experiences and prospects, eds. A. Kukliński, B. Jałowiecki, Region, Local Studies, 5, Univ. Warsaw, Warsaw

Chojnicki Z. 1991, Podstawowe problemy metodologiczne rozwoju polskiej geografii, UAM, Seria Geographica, 48

Chojnicki Z. 1977, Metody ilościowe i modele w geografii, PWN, Warszawa

Chojnicki Z. 1999, Podstawy metodologiczne i teoretyczne geografii, Bogucki Wydawnictwo Naukowe, Poznań

Chojnicki Z. 2001, Dualizm metodologiczny w geografii spoteczno-ekonomicznej, [w:] Koncepcje teoretyczne i metody badań geografii spoteczno-ekonomicznej i gospodarki przestrzennej, red. H. Rogacki, Bogucki Wydawnictwo Naukowe, Poznań

Chojnicki Z. 2002, Wyjaśnianie w geografii spoleczno-ekonomicznej w ujęciu relacjonistycznym, [w:] Możliwości i ograniczenia zastosowań metod badawczych $w$ geografii spoteczno-ekonomicznej i gospodarce przestrzennej, red. H. Rogacki, Bogucki Wydawnictwo Naukowe, Poznań

Czerny M. 2001, Globalizacja a rozwój lokalny w geografii spoleczno-ekonomicznej, [w:] Koncepcje teoretyczne i metody badań geografii spoleczno-ekonomicznej i gospodarki przestrzennej, red. H. Rogacki, Bogucki Wydawnictwo Naukowe, Poznań

Czerny M. 2005, Globalizacja a rozwój. Wybrane zagadnienia z geografii spoteczno-gospodarczej świata, Wydawnictwo Naukowe PWN, Warszawa

Czerny M., Łuczak R., Makowski J. 2007, Globalistyka, Procesy globalne i ich lokalne konsekwencje, PWN, Warszawa

Domański B. 1963, Zespoły sieci komunikacyjnych, Instytut Geografii PAN, Prace Geograficzne nr 41

Domański B. 1976, Zarys teorii procesów w systemie osadniczym, „Przegląd Geograficzny”, z. 2

Domański B. 1977, Dynamika systemów przestrzennych. Model procesów przestrzennych, „Przegląd Geograficzny", z. 3

Domański B. 1980, Naczelne twierdzenie teorii rozwoju systemu osadniczego, „Przegląd Geograficzny”, z. 4

Domański B. 1982, Modelowanie przekształceń sieci osadniczej w regionach rolniczych, „Ruch Prawniczy, Ekonomiczny i Socjologiczny", z. 2

Domański B. 1987, Teoretyczne podstawy geografii ekonomicznej, PWE, Warszawa

Domański B. 1996, Wpływ inwestycji zagranicznych na gospodarkę województwa, [w:] Raport o stanie inwestycji zagranicznych w województwie krakowskim, Urząd Miasta Krakowa, Kraków

Domański B. 2001a, Deformacje metodologiczne i ideologiczne w badaniach przekształceń przestrzeni gospodarczej Europy Środkowej i Wschodniej, [w:] Koncepcje teoretyczne i metody badań geografii spoleczno-ekonomicznej i gospodarki przestrzennej, red. H. Rogacki, Bogucki Wydawnictwo Naukowe, Poznań 
Domański B. 2001b, Kapitał zagraniczny w przemyśle Polski, Instytut Geografii i Gospodarki Przestrzennej UJ, Kraków

Domański B. 2002, Zagraniczne inwestycje przemysłowe a obszary metropolitalne, Prace Komisji Geografii Przemysłu PTG nr 4, Warszawa-Kraków

Domański R. 2003, Nowe kierunki badawcze w regionalistyce. Nowe doświadczenia polityki regionalnej, Biuletyn KPZK PAN, z. 204

Druckner P.F. 1985, Odejście od cyklu depresji, „Życie Gospodarcze”, 8, z dn. 24.02

Gierańczyk W. 2003, Wybrane aspekty konkurencyjności polskiego przemysłu w dobie globalnych wyzwań rozwoju, [w:] Przemyst w procesie globalizacji, red. Z. Zioło, Z. Makieła, Prace Komisji Geografii Przemysłu PTG, nr 6, Warszawa-Kraków

Gierańczyk W., Stańczyk A. 2003, Korporacje międzynarodowe w przestrzeni globalnej, [w:] Przemyst w procesie globalizacji, red. Z. Zioło, Z. Makieła, Prace Komisji Geografii Przemysłu PTG, nr 5, Warszawa-Kraków

Gorynia M., Owczarek R. 2004, Podstawy teorii internacjonalizacji i globalizacji działalności przedsiębiorstw, „Gospodarka Narodowa”, nr 1-2 (149-150)

Harvey D. 1969, Explanation in Geography, Arnold, London

Jędrzejczyk D. 2002, Geograficzne aspekty globalizacji społeczeństwa i gospodarki, [w:] Geograficzne uwarunkowania rozwoju Małopolski, red. Z. Górka, A. Jelonek, Kraków

Markowski T. 2003, Procesy globalizacji w gospodarce a trendy w badaniach regionalnych, [w:] Nowe kierunki badawcze w regionalistyce. Nowe doświadczenia polityki regionalnej, red. R. Domański, Biuletyn PAN KPZK, z. 204

Makieła Z. 2003, Przejawy procesu globalizacji w rozwoju infrastruktury transportowej w Polsce, [w:] Przemyst w procesie globalizacji, red. Z. Zioło, Z. Makieła, Prace Komisji Geografii Przemysłu PTG, nr 6, Warszawa-Kraków

Mesarovic M.D. (ed.) 1964, Foundation for a General Systems Theory, New York

Nagel E. 1961, The structure of science, Harcourt, New York

Rembowska K. 2001, Kulturowa płaszczyzna interpretacyjna geografii społeczno-ekonomicznej, [w:] Koncepcje teoretyczne i metody badań geografii społeczno-ekonomicznej i gospodarki przestrzennej, red. H. Rogacki, Bogucki Wydawnictwo Naukowe, Poznań

Rykiel Z. 1991, Koncepcje geografii społecznej, [w:] Studia z geografii społecznej, red. Z. Rykiel, Dokumentacja Geograficzna, z. 3-4, IGiPZ, Wrocław-Warszawa-Kraków

Rykiel Z. 2001, Gtówne nurty filozoficzne, teoretyczne i metodologiczne w teorii regionu społecznoekonomicznego, [w:] Koncepcje teoretyczne i metody badań geografii społeczno-ekonomicznej i gospodarki przestrzennej, red. H. Rogacki, Bogucki Wydawnictwo Naukowe, Poznań

Sala S. 2003, Wybrane cechy działalności KTN $i$ ich implikacje dla Polski, [w:] Przemyst w procesie globalizacji, red. Z. Zioło, Z. Makieła, Prace Komisji Geografii Przemysłu PTG, nr 6, WarszawaKraków

Stryjakiewicz T. 2001, Koncepcja usieciowienia (networking) w badaniach przestrzenno-ekonomicznych, [w:] Koncepcje teoretyczne i metody badań geografii spoteczno- ekonomicznej i gospodarki przestrzennej, red. H. Rogacki, Bogucki Wydawnictwo Naukowe, Poznań

Stryjakiewicz T. 1988, Czynniki lokalizacji i funkcjonowania przemysłu rolno-spożywczego oraz jego struktura przestrzenna w regionie poznańskim, Wydawnictwo Naukowe UAM, Poznań

Wieloński A. 2003, Przemyst Nowej Gospodarki, [w:] Przemyst w procesie globalizacji, red. Z. Zioło, Z. Makieła, Prace Komisji Geografii Przemysłu PTG, nr 5, Warszawa-Kraków

Zioło Z. 2003, Ksztaltowanie się przedsiębiorstw przemystowych w procesie globalizacji, [w:] Przemyst w procesie globalizacji, Prace Komisji Geografii Przemysłu PTG, nr 6, red. Z. Zioło, Z. Makieła, Warszawa-Kraków

Zioło Z. 1999, Transformacja struktur subregionalnych Polski Poludniowo-Wschodniej w okresie zmian systemu gospodarowania, Wyd. PAN, Kraków 


\section{Selected methodological problems in research into globalization processes}

The paper presents an attempt to identify methodological problems in the research into the processes of globalization. Originally globalization was treated as a homogeneous process, leaving its impress on the ground of economic and social sciences. Later, however, scientists realized that globalization triggers a lot of processes, part of which are known, but many of which we are not aware of. In this context, it is more proper to write and talk not about globalization but about the processes of globalization. The author understands the processes of globalization as a whole of the processes which occur on the social- economic and political plane. The processes lighten mutual connections between countries, regions or single people, and their consequences.

According to the author, the main problems in the research into processes of globalization are: problems with defining the subject of research, lack of proper methodology and methods of research, interdisciplinary problems and problems with objectivity of facts.

The selection of proper research methods to conduct the research into the processes of globalization poses a lot of difficulties. They result from the fact that geography has worked out a lot of detailed research methods, used to describe quantitative phenomena, which are the essence of globalization, using qualitative methods. At this stage of research, the essence of globalization can be captured by using systematic approach in an idiographic sense. 